“C 2011 IEEE. Personal use of this material is permitted. Permission from IEEE must be obtained for all other uses, in any current or future media, including reprinting/republishing this material for advertising or promotional purposes, creating new collective works, for resale or redistribution to servers or lists, or reuse of any copyrighted component of this work in other works." 


\title{
Transformer-Less Local Grid Based 11 kV SCHB Multilevel Converter for Renewable Energy Systems
}

\author{
Md. Rabiul Islam *, Youguang Guo and Jian Guo Zhu \\ School of Electrical, Mechanical and Mechatronic Systems, University of Technology Sydney, NSW, Australia \\ *E-mail: Md.Islam@uts.edu.au, rabiulbd@hotmail.com
}

\begin{abstract}
Due to the variable nature of renewable energy resources and power demand by the consumers, it is difficult to operate a power system installed with only one type of renewable energy resource. The local grid based renewable generation may be the only solution to overcome this problem. In this regard, an $11 \mathrm{kV}$ Series Connected H-Bridge (SCHB) multilevel Voltage Source Converter (VSC) is proposed, which is the transformer less, cost effective solution to interface the renewable generation system to the local grid directly. This paper presents the design, simulation and analysis of a Five Level (5L)-SCHB and an Eleven Level (11L)-SCHB VSC for an $11 \mathrm{kV}$ local grid based renewable energy systems. The performance, cost, modulation scheme and harmonic spectra of the converter are the bases for analysis.
\end{abstract}

Keywords - Multilevel converter, transformer-less, renewable energy systems, local grid, MATLAB simulation.

\section{INTRODUCTION}

Two major global crises that mankind is facing currently, are the energy crisis and the environment/climate crisis. The dynamic growth of renewable energy directly pushes the renewable energy technology into a more competitive area. Hence during the last decades, renewable energy resources have become an important part of the worldwide concern with clean power generation and scientists and researchers have been trying to find out the effective technologies for the renewable generation system. Many countries have set the target of renewable energy use to meet the increasing power demand and also to reduce the greenhouse effect. The target share of final energy from renewables of some countries is shown in Table I [1].

TABLE I

RENEWABLE ENERGY TARGETS

\begin{tabular}{|l|c|c|}
\hline Country & Year & Renewable (\%) \\
\hline Australia & 2020 & 20 \\
\hline Denmark & 2025 & 50 \\
\hline Finland & 2020 & 38 \\
\hline France & 2020 & 23 \\
\hline Germany & 2020 & 18 \\
\hline UK & 2020 & 15 \\
\hline US & 2025 & 25 \\
\hline Sweden & 2020 & 49 \\
\hline Austria & 2020 & 34 \\
\hline
\end{tabular}

The solar and wind are main renewable energy sources for the future electricity supply. The global renewable energy achievement rate from these two sources is also high. Solar Photovoltic (PV) generates electricity in well over 100 countries and continues to be the fastest growing renewable source in the world. Between 2004 and 2009, grid connected
PV capacity increased at an annual average rate of $60 \%$ and over this five year period, annual growth rates for cumulative wind power capacity averaged $27 \%$. The capacity installed in 2009 is equivalent to nearly a quarter of total global installations, and cumulative capacity has doubled in less than three years. The global installed wind power capacity is shown in Fig. 1 [2].

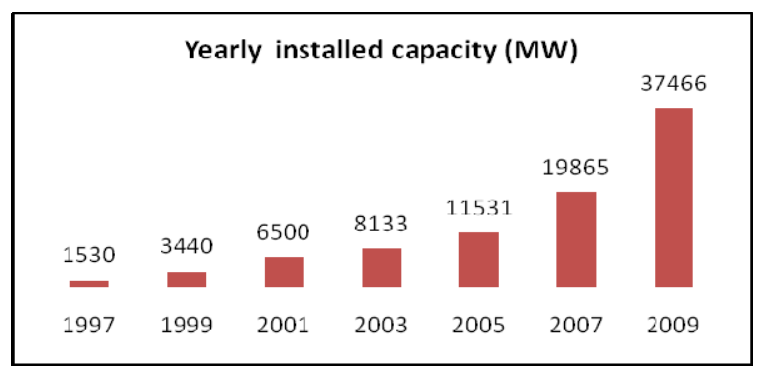

(a)

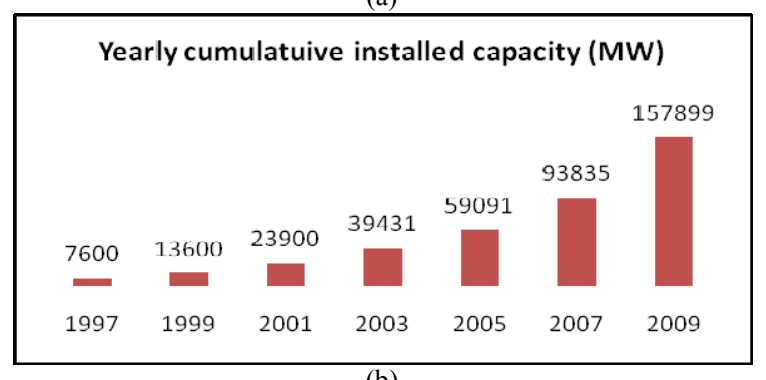

(b)

Fig. 1. Global installed wind power capacity: (a) annual, (b) cumulative

The availability of renewable energy sources has strong daily and seasonal patterns and the power demand by the consumers could have a very different characteristic. So, it is difficult to operate a power system installed with only one type of renewable energy resource. The grid based renewable generation may be the only solution to overcome this problem but due to the variable nature of renewable energy sources, output voltage and frequency adjustments are the challenging issues to connect these systems to power grids. Different power electronic converters have been developed using conventional topologies to fulfill the requirements of renewable generations [3]. All of them contain magnetic components, e.g. transformer, which not only increase the size, weight and loss but also increase the cost and complexity of the system operation. An isolation transformer represents $30 \%$ to $50 \%$ of a total system size and $50 \%$ to $70 \%$ of the system's weight [4]. An 1-MVA transformer generates a big 
amount of heat energy (up to $6800 \mathrm{Btu} / \mathrm{h}$ ) and requires a significant amount of air conditioning. Thus, the transformerless solutions result in large amount of energy savings.

To reduce the size and weight of the power transformer different topologies in literature have been presented [5]. All of the topologies are based on high frequency link. The high frequency link based power electronic transformer also contains a high frequency transformer, whose insulation and the high voltage and high frequency operation of power switches are challenging issues. Moreover the system power loss also increases.

In order to stabilize the system operation the harmonic control is also important. To mitigate this harmonic effect it is essential to use a filter coil, which also increases the system complexity and cost. Although the continuous race to develop higher voltage and higher current power semiconductors to drive high power systems goes on but it is still hard to connect a single power semiconductor switch directly to high voltage grid (e.g. $11 \mathrm{kV})$ [6]. The series-parallel connection of lower rated semiconductors could be the cost effective solution for high voltage applications.

A new family of multilevel converter has emerged as the solution for working with medium/ high voltage applications. There are three most popular topologies in multilevel converters: Neutral Point Clamped (NPC), Flying Capacitor (FC) and SCHB [7], [8]. In recent years they have more attraction due to some special features like better harmonic performance, drawing input current with very low distortion, lower voltage stress in power semiconductor switches and lower switching frequency capability, compared to others.

Output voltage waveforms of the converter could be improved by increasing the level of the converter, which may reduce the size of the input and output filter requirements. The $\%$ of Total Harmonic Distortion (THD) of different level inverter is shown in Table II. The cascaded/multilevel connection of low rated voltage devices could be the possible cost effective solution of high voltage high power applications. As a result, it is now required and not difficult to develop an $11 \mathrm{kV}$ multilevel VSC, which can be able to connect the renewable generation system to the local grid without introducing a power transformer.

TABLE II

HARMONICS COMPARISON OF THE INVERTERS

\begin{tabular}{|c|c|c|c|c|}
\hline Level & $2 \mathrm{~L}$ & $3 \mathrm{~L}$ & $5 \mathrm{~L}$ & $11 \mathrm{~L}$ \\
\hline THD (\%) & 107 & 42 & 17.26 & 7.07 \\
\hline
\end{tabular}

Among these three multilevel converter topologies the NPC and FC topologies have the disadvantage that the number of components scales quadratically and capacitor voltage balancing problems become intractable with respect to the number of levels. In this regard the SCHB topology is suitable for high voltage as well as high level converter but many publications have addressed the limitation of the SCHB converter since the requirements of multiple-isolated DC sources, and therefore its application is not straightforward [9]. Multiple independent generator stator windings and multistring photovoltaic configurations are possible solutions to overcome the above limitation. This paper proposes transformer-less SCHB multilevel converter for an $11 \mathrm{kV}$ local grid based renewable generation systems. Fig. 2 shows the basic block diagram of the proposed converter. The converter is designed and performance is simulated and also cost of power semiconductors and passive components is calculated.

\section{DESIGN AND SPECIFICATION}

Each conversion unit has individual $\mathrm{AC}$ to $\mathrm{DC}$ and/or DC to DC booster with Maximum Power Point Tracker (MPPT), which feed energy into a common DC to AC inverter as shown in Fig. 2. The inverter is directly connected to the grid through a small size filter. This topology provides more flexibility to control each renewable energy conversion unit individually. The operating conditions and basic converter data are shown in Table III.

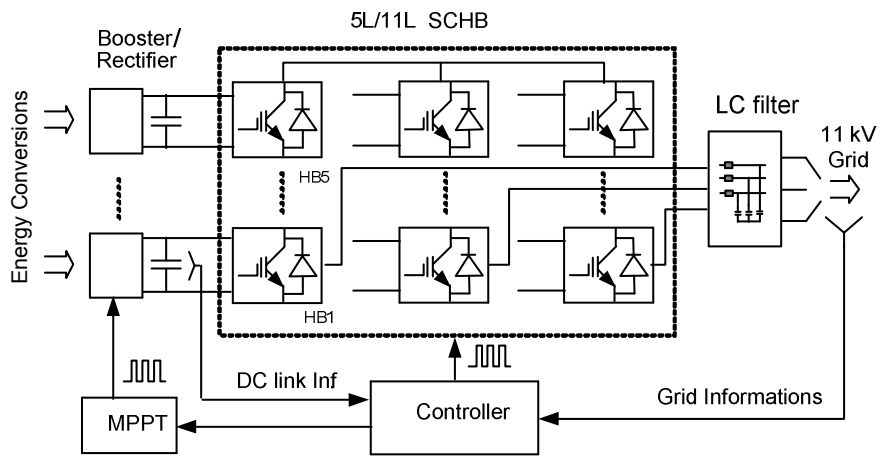

Fig. 2. Basic block diagram of 5L/11L SCHB VSC.

TABLE III

BASIC CONVERTER DATA

\begin{tabular}{|l|c|c|}
\hline \multicolumn{1}{|c|}{ Technical Data } & Abbreviations & Value \\
\hline Converter line-to-line voltage & $V_{l l(r m s)}$ & $11 \mathrm{kV}$ \\
\hline Minimum DC-link voltage & $V_{d c(\text { min })}$ & $15556 \mathrm{~V}$ \\
\hline Nominal DC-link voltage & $V_{d c(\text { nom })}$ & $16179 \mathrm{~V}$ \\
\hline Phase current & $I_{p(r m s)}$ & $250 \mathrm{~A}$ \\
\hline Apparent converter output power & $S_{c}$ & $4.76 \mathrm{MVA}$ \\
\hline Converter carrier frequency & $f_{c}$ & $1-2 \mathrm{kHz}$ \\
\hline Output frequency & $f_{o}$ & $50 \mathrm{~Hz}$ \\
\hline
\end{tabular}

\section{A. Inverter Section}

The 5L/11L-SCHB multilevel VSC topology is used to implement the inverter section of the proposed systems. The overall system performance highly depends on the performance of this section. So, it is required to give more careful attention to select the inverter topology. The semiconductor utilization is a very important part to evaluate high-voltage topologies due to the high share of semiconductor costs. The minimum DC-link voltage necessary to achieve an output line-to-line voltage of $11 \mathrm{kV}$ can be calculated from

$$
V_{d c(\min )}=\sqrt{2} \times V_{l l(r m s)}
$$

To determine the nominal DC-link voltage of the converter, a voltage reserve of $4 \%$ is assumed [10], i.e.

$$
V_{d c(\text { nom })}=1.04 \times V_{d c, \text { min }}
$$




$$
=1.04 \times 15556.4 \mathrm{~V}=16.179 \mathrm{kV}
$$

The apparent converter output power can be calculated using

$$
S_{c}=\sqrt{3} \times V_{l l(r m s)} \times I_{p(r m s)}=\sqrt{3} \times 11 \mathrm{kV} \times 250 \mathrm{~A}=4.76 \mathrm{MVA}
$$

The DC-link voltage needs to be considered when selecting IGBTs and diodes voltage ratings; and cosmic ray effects assessment may also be necessary. In addition to the output capacity and voltage ratings of the converter, the availability of IGBT and diode modules in the market needs to be considered in design process. Two $4.5 \mathrm{kV}$ series-connected IGBTs are assumed as a single switch for all the 5L converter topologies. Table IV summarizes the design of the power semiconductors for the inverter section, with a carrier frequency of 1-2 kHz. To enable a converter output phase current of $250 \mathrm{~A}$, a $400 \mathrm{~A} / 360 \mathrm{~A}(5 \mathrm{~L} / 11 \mathrm{~L})$ current rating is chosen for the power semiconductors.

TABLE IV

IGBT'S RATING

\begin{tabular}{|l|c|c|}
\hline & 5L-SCHB & $11 \mathrm{~L}-\mathrm{SCHB}$ \\
\hline Nominal DC voltage (each source) & $4045 \mathrm{~V}$ & $1618 \mathrm{~V}$ \\
\hline IGBT's voltage rating & $2 \times 4.5 \mathrm{kV}$ & $3.3 \mathrm{kV}$ \\
\hline $\begin{array}{l}\text { Commutation voltage of respective } \\
\text { commutation cells, } V_{\text {com }}\end{array}$ & $2022 \mathrm{~V}$ & $1618 \mathrm{~V}$ \\
\hline $\begin{array}{l}\text { Device commutation voltage for a } \\
\text { device reliability of 100FIT due to } \\
\text { cosmic radiation, } V_{\text {com@100FIT }}\end{array}$ & $2 \times 2250 \mathrm{~V}$ & $1800 \mathrm{~V}$ \\
\hline $\begin{array}{l}\text { Device voltage utilization factor, } \\
V_{\text {com }} / V_{\text {com @100FIT }}\end{array}$ & 0.90 & 0.90 \\
\hline IGBT's current rating & $400 \mathrm{~A}$ & $360 \mathrm{~A}$ \\
\hline
\end{tabular}

\section{B. Rectifier Section}

Generation side power flow control, Maximum Power Point Tracking (MPPT) is implemented through booster section. Therefore, diode bridge rectifier is the best choice to simplify the circuit and reduce the system cost. The PV array provides DC power, so this section is not required for PV based renewable energy systems. The rms output voltage of commonly used wind generator is $690 \mathrm{~V}$. If the renewable energy conversion unit output line voltage is $690 \mathrm{~V} \mathrm{rms}$, then the DC output voltage of three phase diode rectifier can be calculated from

$$
V_{d c(\text { recti })}=1.654 \times V_{m}=932 \mathrm{~V}
$$

where $\mathrm{V}_{\mathrm{m}}(563 \mathrm{~V})$ is the peak value of the phase voltage. The peak inverse voltage (PIV) can also be calculated from

$$
P I V=\sqrt{3} \times V_{m}=976 \mathrm{~V}
$$

The rating of power components is shown in Table $\mathrm{V}$.

TABLE V

POWER COMPONENTS IN THE RECTIFIER

\begin{tabular}{|l|l|l|}
\hline & $5 \mathrm{~L}-\mathrm{SCHB}$ & $11 \mathrm{~L}-\mathrm{SCHB}$ \\
\hline Unit voltage (rms) & $690 \mathrm{~V}$ & $690 \mathrm{~V}$ \\
\hline Average output voltage & $932 \mathrm{~V}$ & $932 \mathrm{~V}$ \\
\hline PIV of the diodes & $976 \mathrm{~V}$ & $976 \mathrm{~V}$ \\
\hline
\end{tabular}

\section{Booster Section with MPPT}

To boost the input voltage to the system DC link levels, the IGBT based booster circuit is used. The magnitude of DC link voltage depends on the level of the inverter. Required DC link voltage can be generated by changing the duty cycle (D) of the IGBT/ MOSFET switch.

The availability of renewable energy sources has strong daily and seasonal patterns. Hence, a power flow control algorithm is implemented through the variation of duty cycle of the IGBT/ MOSFET switch to maintain the converter output voltage. Without an MPPT the system are connected directly to the load. This forces the system to operate at the load voltage, but this is typically not the optimal operating voltage at which the modules are able to produce their maximum power. The boost converter reflects high load impedance to low impedance on the source side.

If the system is required to operate at or near the Maximum Power Point (MPP) of the system without changing the load, the impedance seen from the converter input side (can be adjusted by changing the duty cycle) needs to match the internal impedance of the system. Fig. 3 shows the basic block diagram of booster section and its component rating is listed in Table VI.

As a result, to maintain constant DC link voltage with MPP operation it is required to determine an optimum duty cycle. The maximum duty cycle ratio is set at $90 \%$ and the minimum is at $10 \%$ to avoid power loss, and hence contributing to the inefficient power transfer of the converter. Table VII shows the relation of duty cycle (\%) versus available input voltage of the renewable source.

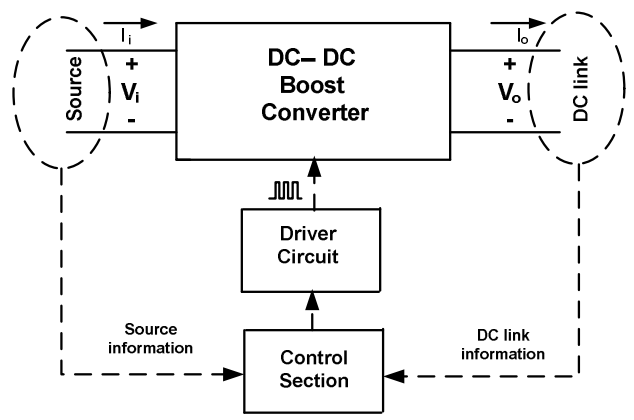

Fig. 3. Basic block diagram of booster section with MPPT and DC link voltage adjustment topology

TABLE VI

POWER COMPONENTS IN THE BOOSTER

\begin{tabular}{|l|c|c|}
\hline & 5L-SCHB & $11 \mathrm{~L}-\mathrm{SCHB}$ \\
\hline PIV of diodes & $4045 \mathrm{~V}$ & $1618 \mathrm{~V}$ \\
\hline Inductor current & $852 \mathrm{~A}$ & $456 \mathrm{~A}$ \\
\hline IGBTs reverse voltage & $4045 \mathrm{~V}$ & $1618 \mathrm{~V}$ \\
\hline IGBTs current rating & $852 \mathrm{~A}$ & $456 \mathrm{~A}$ \\
\hline
\end{tabular}

TABLE VII

BOOSTER DC LINK VOLTAGE ADJUSTMENT (11L-SCHB)

\begin{tabular}{|c|c|c|}
\hline $\begin{array}{c}\text { Available input } \\
\text { voltage (V) }\end{array}$ & $\begin{array}{c}\text { DC link voltage } \\
(\mathrm{V})\end{array}$ & $\begin{array}{c}\text { Required duty } \\
\text { cycle (\%) }\end{array}$ \\
\hline $162(\mathrm{~min})$ & 1618 & 90 \\
\hline 200 & 1618 & 88 \\
\hline 400 & 1618 & 75 \\
\hline 600 & 1618 & 63 \\
\hline 800 & 1618 & 51 \\
\hline 932 (rated) & 1618 & 42 \\
\hline 1000 & 1618 & 38 \\
\hline 1200 & 1618 & 26 \\
\hline 1400 & 1618 & 14 \\
\hline 1456 (max) & 1618 & 10 \\
\hline
\end{tabular}




\section{Modulation Scheme}

Different modulation schemes have been adapted or developed depending on the application and the converter topology, and each has its unique advantages and disadvantages. The most common modulation method in industry is carrier based sine triangle modulation. The Phase Shifted-Sine Pulse Width Modulation (PS-SPWM) method is especially useful for Series Cascaded H-Bridge (SCHB) converters [11]. In this paper a PS-SPWM scheme is used to analyze the converter performance. Fig. 4 shows the PSSPWM scheme for 5L-SCHB converter where switching pulse generating signals of two successive cells are shown separately in (b) and in (c). The modulation scheme for 11LSCHB multilevel converter is show in Fig. 5.

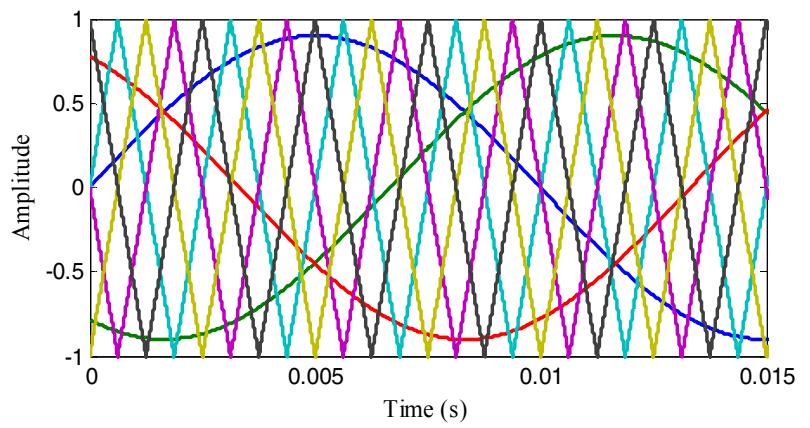

(a)

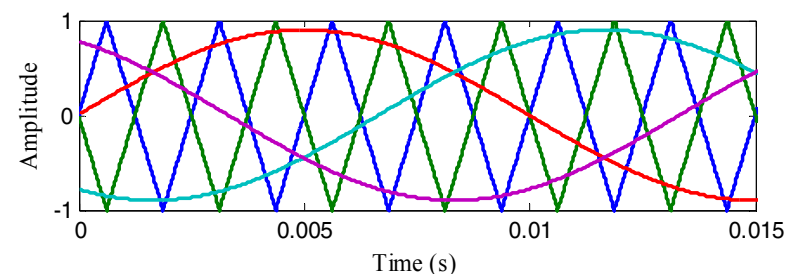

(b)

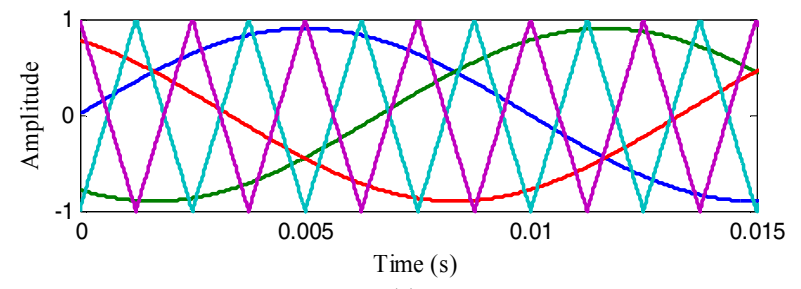

(c)

Fig. 4. Modulation schemes for 5L-SCHB VSC: (a) all cells, (b) and (c) two successive cells.

\section{Simulation Results}

The performance is analyzed and compared in Matlab/Simulink environment. To generate switching pulses a PS-SPWM scheme is used for SCHB topology with a carrier frequency of $1-2 \mathrm{kHz}$ and modulation index of $0.8-0.9$. $5 \mathrm{~L}$ converter output line voltage at the inverter terminal is shown in Fig. 6 and line voltage at the load terminal is shown in Fig. 7. Fig. 8 shows its line current. The respective harmonic spectra are shown in Fig. 9 to Fig. 11. 11L converter's output line voltage at inverter terminal and at load terminal and the line current are shown in Fig. 12 to Fig. 14 and also their harmonic spectra are shown in Fig. 15 to Fig. 17.

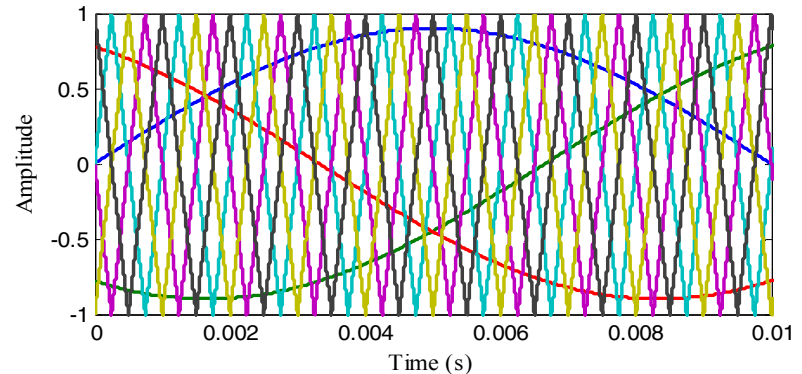

(a)

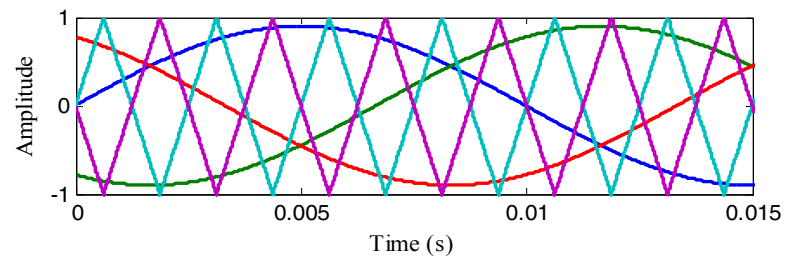

(b)

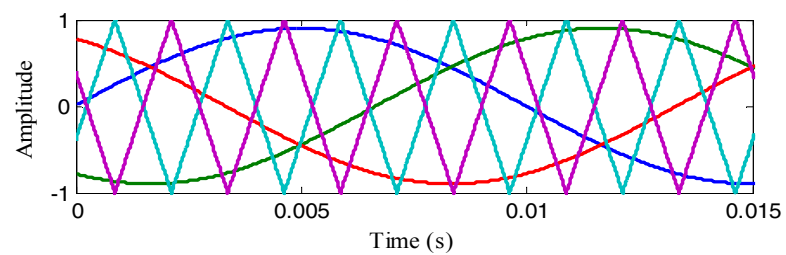

(c)

Fig. 5. Modulation schemes for 11L-SCHB VSC: (a) all cells, (b) and (c) two successive cells.

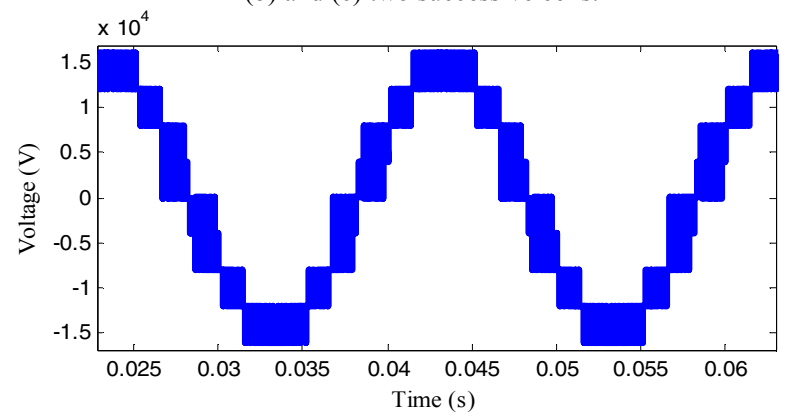

Fig. 6. Line voltage of $5 \mathrm{~L}-\mathrm{SCHB}$ VSC at inverter terminal.

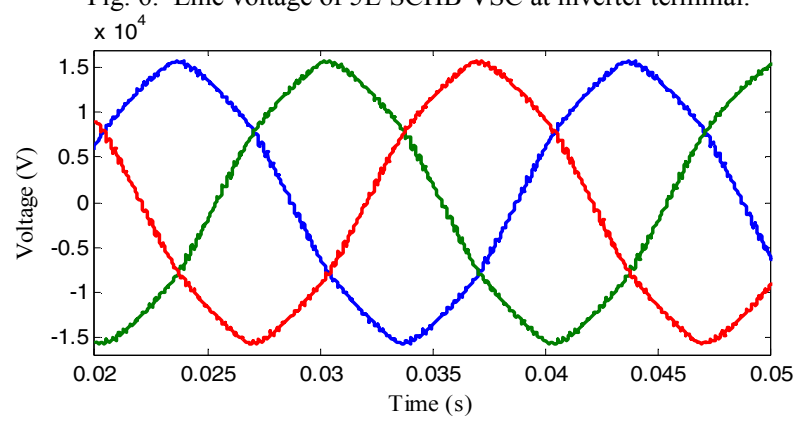

Fig. 7. Line voltage of 5L-SCHB VSC (at load terminal).

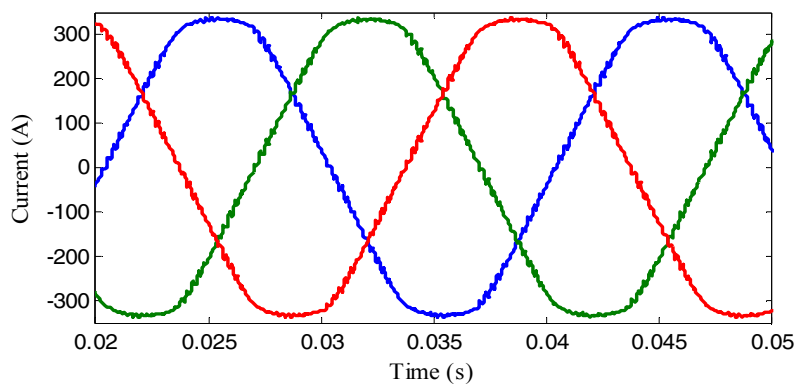

Fig. 8. Line current of 5L-SCHB VSC. 


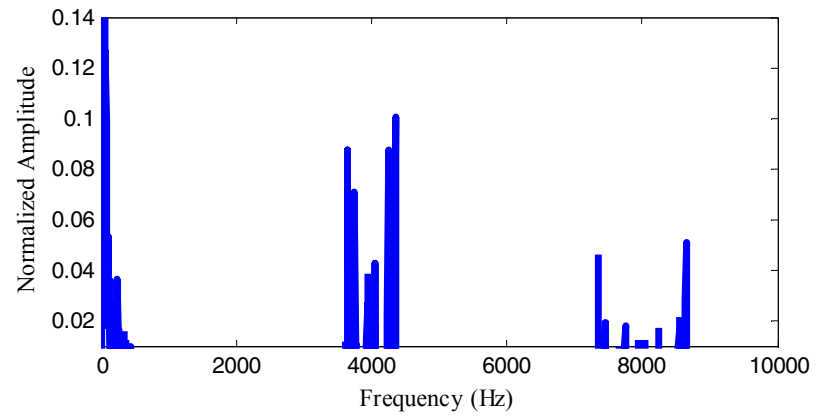

Fig. 9. Line voltage harmonic spectrum of 5L-SCHB VSC at inverter.

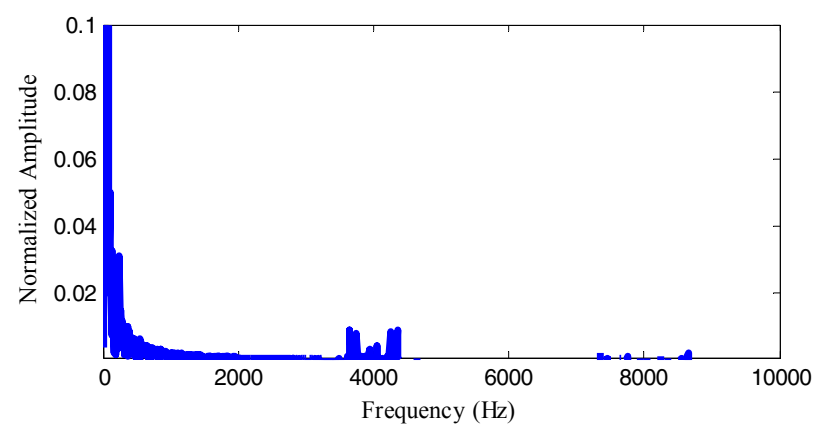

Fig. 10. Line voltage harmonic spectrum of 5L-SCHB VSC at load.

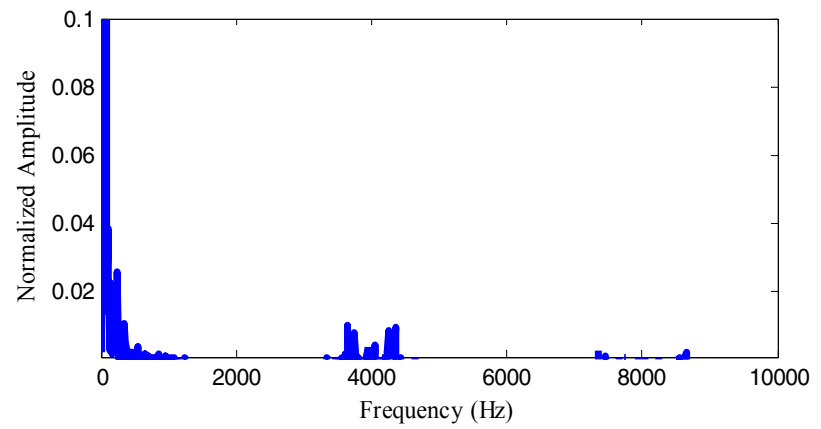

Fig. 11. Line current harmonic spectrum of 5L-SCHB VSC.

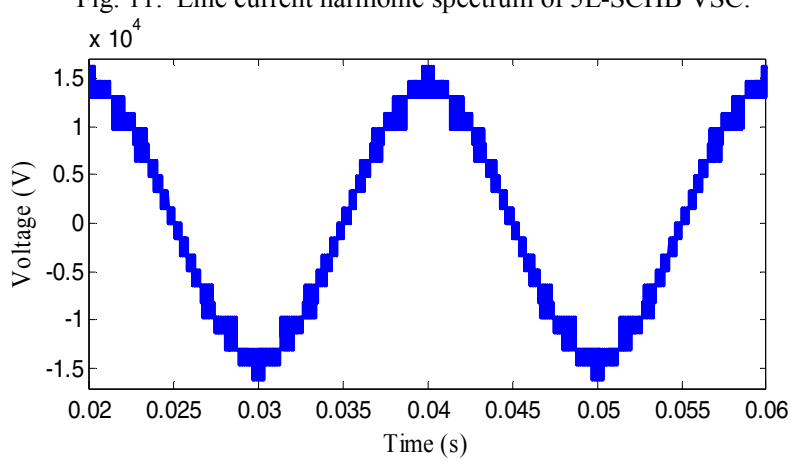

Fig. 12. Line voltage of $11 \mathrm{~L}-\mathrm{SCHB}$ VSC (at inverter terminal).

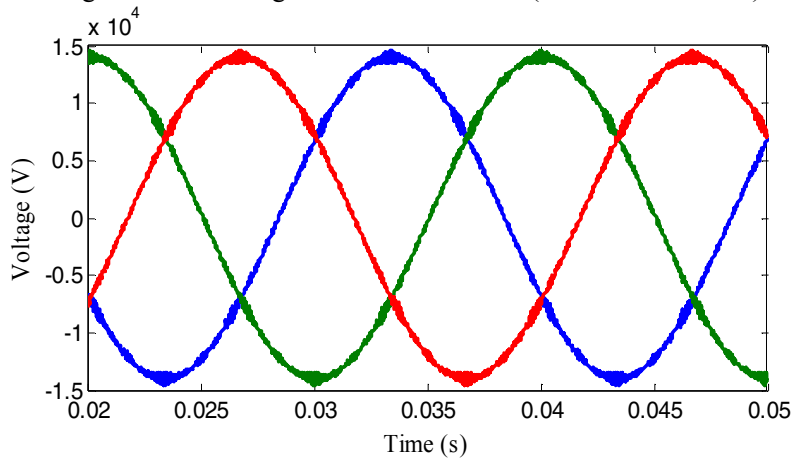

Fig. 13 Line voltage of 11L-SCHB VSC at load.

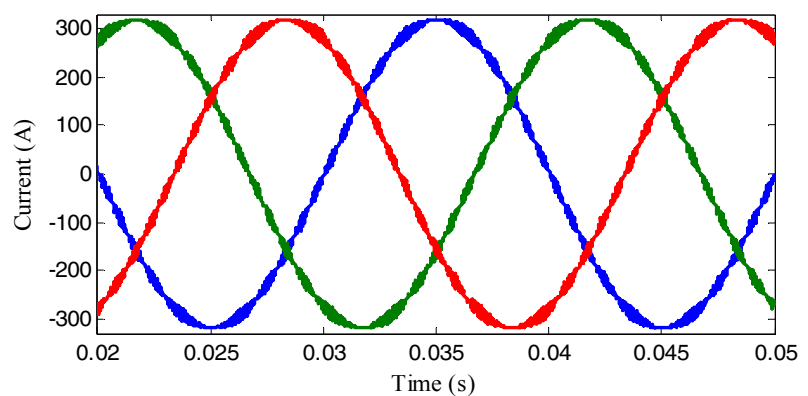

Fig. 14 Line current of 11L-SCHB VSC.

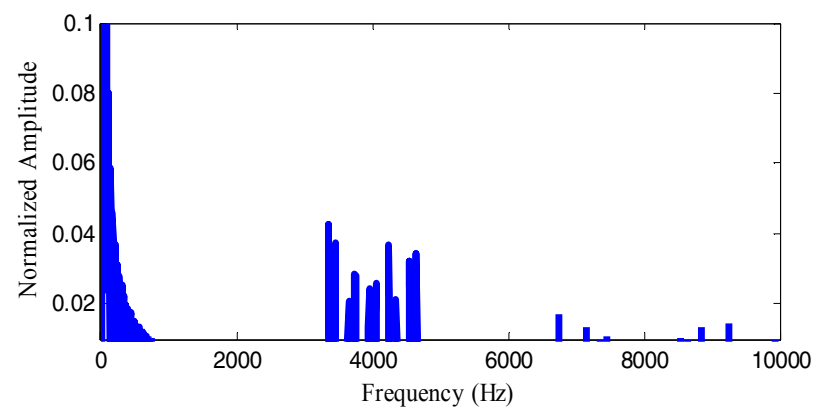

Fig. 15 Line voltage harmonic spectrum of $11 \mathrm{~L}-\mathrm{SCHB}$ VSC at inverter.

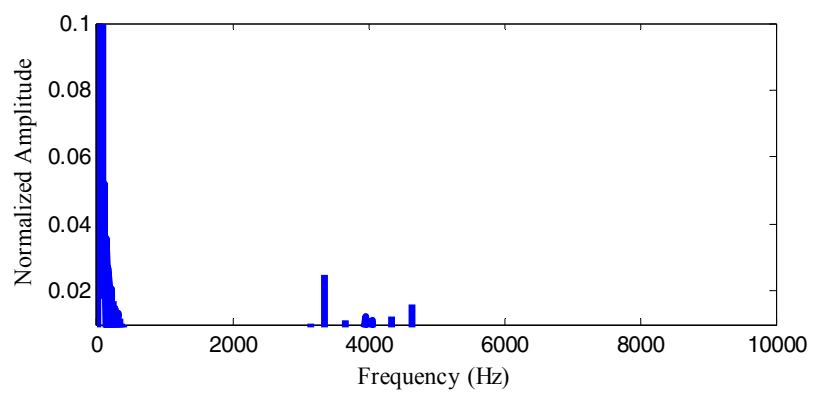

Fig. 16 Line voltage harmonic spectrum of 11L-SCHB VSC at load.

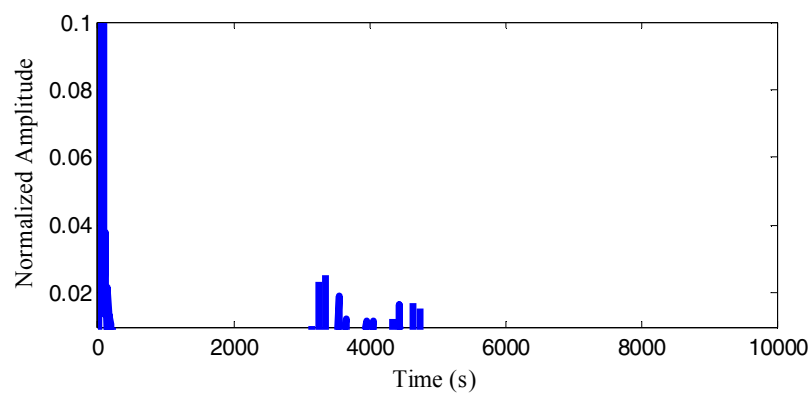

Fig. 17 Line current harmonic spectrum of 11L-SCHB VSC.

\section{PERFORMANCE AND COST}

The harmonic content decreases rapidly with increasing number of levels. Table VIII shows the THD for both multilevel converter output voltage and current. The size of the LC filter also reduces. This means that by increasing the levels of the converter, it is possible to keep the output voltage total harmonic distortion to less than, or equal to $5 \%$ (according to IEEE standard 519-1999). In this way the SCHB converter is more economical than the others $(\mathrm{NPC} / \mathrm{FC})$ because it is easy to increase the level numbers.

LC filter is used to improve the output harmonic performance of both converters, which is less than $5 \%$. Among these two converters, the 5L-SCHB converter system 
requires relatively larger size filter than the $11 \mathrm{~L}-\mathrm{SCHB}$ system. It is also observed that, the harmonic performance of the SCHB topology having a level number of 19 is good enough (less than 5\% harmonic distortion) to connect the converter to the local grid directly, without using filter.

TABLE VIII

CONVERTER Performance

\begin{tabular}{|l|c|c|}
\hline & 5L-SCHB & 11L-SCHB \\
\hline $\begin{array}{l}\text { THD (\%) in line voltage at } \\
\text { inverter terminal }\end{array}$ & 20 & 9 \\
\hline THD (\%) in line current & 3.1 & 2.5 \\
\hline
\end{tabular}

There are no blocking diodes or clamping capacitors in SCHB multilevel converter topology. The component numbers of this topology scale linearly with the number of levels. Hence, the overall number of total components is much lower than other topologies. The numbers of power components for each converter topologies are listed in Table IX. The individual modules are similar and totally modular in construction, which makes it easy to implement for any levels. Hence, SCHB converter is the low cost high performance converter and it is suitable for the connection of an $11 \mathrm{kV}$ system directly. The price data quoted for the semiconductor devices and capacitors were collected from the Galco Industrial Electronics and Farnell catalogues [12], [13] where devices were chosen from the same family so that it was possible to fit with requirements. The filter inductor and booster inductor are custom designs. Therefore, their costs depend on the design. The material costs of the inductor can thus be estimated. The IGBTs chosen are with integrated freewheel diodes and hence these diodes do not appear in costings. The current rating of most of devices is selected on the basis of simulation results. Table $\mathrm{X}$ also shows the estimated cost of two converter systems.

TABLE IX

NUMBER OF POWER COMPONENTS

\begin{tabular}{|c|l|c|c|}
\hline & & 5L-SCHB & 11L-SCHB \\
\hline \multirow{4}{*}{ Inverter section } & Number of IGBTs & $24+24$ & 60 \\
\cline { 2 - 4 } & Sub total & 48 & 60 \\
\hline \multirow{5}{*}{ Beoster section } & Number of inductors & 6 & 15 \\
\cline { 2 - 4 } & Number of IGBTs & $2 \times 6$ & 15 \\
\cline { 2 - 4 } & Number of diodes & 6 & 15 \\
\cline { 2 - 4 } & $\begin{array}{l}\text { Number of DC link } \\
\text { capacitors }\end{array}$ & 6 & 15 \\
\cline { 2 - 4 } & Sub total & 30 & 60 \\
\hline All sections & Number of diodes & 36 & 90 \\
\cline { 2 - 4 } & $\begin{array}{l}\text { Number of filter } \\
\text { capacitors }\end{array}$ & 6 & 15 \\
\cline { 2 - 4 } & Sub total & 42 & 105 \\
\hline & Total component count & 120 & 225 \\
\hline
\end{tabular}

The number of semiconductor increases with the number of levels but the change of cost is small because the price of the low rated voltage devices are comparatively very low. Because of the lower voltage and current requirements, the total semiconductor cost of the 11L-SCHB converter is lower than 5L-SCHB converter system.

\section{CONCLUSION}

The component numbers of the SCHB converter scale linearly with the number of levels. Due to the identical modular nature the construction it is easy to attain high level numbers. The high number of levels means that output filter sizes can be minimized, and allowing the possibility of direct connection to the medium or high voltage network. This direct connection means elimination of heavy, bulky, lossy and costly transformers from the system. Multiple independent generator stator windings and multistring photovoltaic configurations are possible solutions to overcome the requirement of isolated sources. According to converter cost, complexity and performance, it is concluded that the SCHB topology is the most feasible for high-voltage applications.

TABLE $X$

ESTIMATED COST FOR POWER COMPONENTS

\begin{tabular}{|c|l|c|c|}
\hline \multirow{4}{*}{$\begin{array}{c}\text { Cost of } \\
\text { semiconductors } \\
\text { (AU\$) }\end{array}$} & Costs of IGBTs (inverter) & $5 \mathrm{~L}-\mathrm{SCHB}$ & $11 \mathrm{~L}-\mathrm{SCHB}$ \\
\cline { 2 - 4 } & Costs of IGBTs (rectifier) & 41,027 & 82,159 \\
\cline { 2 - 4 } & Costs of diodes (rectifier) & 4,486 & 12,750 \\
\cline { 2 - 4 } & $\begin{array}{l}\text { Total cost of } \\
\text { semiconductors }\end{array}$ & 127,527 & 97,712 \\
\hline \multirow{3}{*}{$\begin{array}{c}\text { Costs of passive } \\
\text { components } \\
\text { (AU\$) }\end{array}$} & Material costs of LC filter & 20,500 & 12,300 \\
\cline { 2 - 4 } & Costs of DC capacitors & 9,288 & 12,480 \\
\cline { 2 - 4 } & Costs of boost inductors & 25,200 & 18,900 \\
\cline { 2 - 4 } & $\begin{array}{l}\text { Total costs of passive } \\
\text { components }\end{array}$ & 54,988 & 43,680 \\
\hline All & Total costs (\$) & 182,515 & 141,392 \\
\hline
\end{tabular}

\section{REFERENCES}

[1] Renewable Energy Policy Network. (June 2011). Renewables 2010 Global Status Report. [Online]. Available at: http://www.ren21.net/ Portals/97/documents/GSR/REN21_GSR_2010_full_revised\%20Sept20 10.pdf

[2] Global Wind Energy Council. (June 2011). Global Wind Report, Annual Market Update 2010. [Online]. Available at: http://www.gwec.net/ fileadmin/images/Publications/GWEC_annual_market_update_2010_2nd_edition_April_2011.pdf

[3] S. Kouro, M. Malinowski, K. Gopakumar and et al., "Recent Advances and Industrial Applications of Multilevel Converters", IEEE Transactions on Industrial Electronics, vol. 57, no. 8, pp. 2553-2580, 2010.

[4] H. Abu-Rub, J. Holtz, J. Rodriguez and G. Baoming, "Medium Voltage Multilevel Converters-State of the Art, Challenges, and Requirements in Industrial Applications," IEEE Transactions on Industrial Electronics, vol. 57, no. 8, pp. 2581-2596, 2010.

[5] M. Sabahi, A. Y. Goharrzi, S. H. Hosseini, M. B. B. Sharifian and G. B. Gharehpetian, "Flexible Power Electronic Transformer", IEEE Transactions on Power Electronics, vol. 25, no. 8, pp. 2159-2169, 2010.

[6] J. Rodriguez, L. G. Franquelo, J. I. Leon and et al, "Multilevel Converters: an Enabling Technology for High-Power Applications", Proceedings of IEEE, vol. 97, no. 11, pp. 1786-1817, 2009.

[7] J. S. Lai and F. Z. Peng, "Multilevel Converters-a New Breed of Power Converters", IEEE Transactions on Industry Applications, vol. 32, no. 3, pp. $509-517,1996$.

[8] A. Nabae, et al., "A New Neutral-Point-Clamped PWM Inverter", IEEE Transactions on Industry Applications, vol. 17, pp. 518-523, 1981.

[9] P. W. Hammond, "A New Approach to Enhance Power Quality for Medium Voltage AC Drives", IEEE Transactions on Industry Applications, vol. 33, pp. 202-208, 1997.

[10] D. Krug, S. Bernet, S. S. Fazel, and et al., "Comparison of $2.3 \mathrm{kV}$ Medium Voltage Multilevel Converters for Industrial Medium Voltage Drives", IEEE Transactions on Industrial Electronics, vol. 54, no. 6, pp. 2979-2992, 2007.

[11] J. Rodriguez, J. S. Lai and F. Z. Peng, "Multilevel Inverters: a Survey of Topologies, Controls, and Applications", IEEE Transactions on Industrial Electronics, vol. 49, no. 4, pp. 724- 738, 2002.

[12] Galco Industrial Electronics. (January 2011). Semiconductors. [Online]. Available at: http://www.galco.com/scripts/cgiip.exe/wa/wcat/catalog. htm

[13] Farnell/Element14. (December 2010). Semiconductor Modules and Passive Components. [Online]. Available at: http://au.element14.com 